NASZA DERMATOLOGIA Online OUR DERMATOLOGY Online

Source of Support: Nil

Competing Interests: None

\section{A RARE CASE OF LEIOMYOMA OVER THE NOSE}

\author{
Harinatha Sreekar ${ }^{1}$, P. Sudarshan ${ }^{1}$, Nithya Raghunath ${ }^{2}$, \\ Vithal Malmande ${ }^{3}$ \\ ${ }^{1}$ Department of General Surgery, MVJ Medical college, Hoskote, Bangalore, India \\ ${ }^{2}$ Department of Dermatology, MVJ Medical College, Hoskote, Bangalore, India \\ ${ }^{3}$ Plastic Surgeon, Apollo Hospital, Bangalore, India
}

Corresponding author: Ass. Prof. Harinatha Sreekar

\title{
Abstract
}

Leiomyoma is an uncommon smooth muscle tumor on the face. Its occurrence is common in the uterus. Though skin lesions have been reported, they are clinically difficult to diagnose as they have features similar to various other swelling. Here we present one such case of leiomyoma over nose that can often be misleading.

Key words: leiomyoma; piloleiomyoma; nose tumor

\section{Introduction}

A leiomyoma can occur in any part of the body. Since the smooth muscle is ubiquitous in its presence, a leiomyoma can occur in virtually any part of a human body. This common lesion can present in various ways and in often unexpected locations. Leiomyomas over the nose are rare and hence are usually missed by an unwary clinician. Here we present one such case which mimicked many different lesions.

\section{Case Report}

A 59 - year - old gentleman presented with a nodular lesion over the tip of his nose. He had the lesion since 20 years and complained of only occasional itching and pain. The area was depressed and scarred from chronic ulceration. (Fig. 1). The lesion was restricted to the skin. The nasal mucosa and the septum were intact clinically. He did not have any co-morbidities or similar lesions elsewhere on his body. The lesion was excised. Since the lesion was restricted to the skin, it was excised in toto and the raw area was covered with a full thickness skin graft. The operated site healed uneventfully.

The histopathologic examination revealed a whorl patterned arrangement of spindle cells. The lesion was well circumscribed into small nodules and was well encapsulated. The nuclei were rod-like and fairly uniform in shape. The stroma was well vascularized with a few areas of hyaline degeneration (Fig. 2a, b). Atypia was mild and mitotic figures were rare. On immunohistochemical analysis, the cytoplasm showed a positive reaction to actin. A diagnosis of leiomyoma was hence reached.

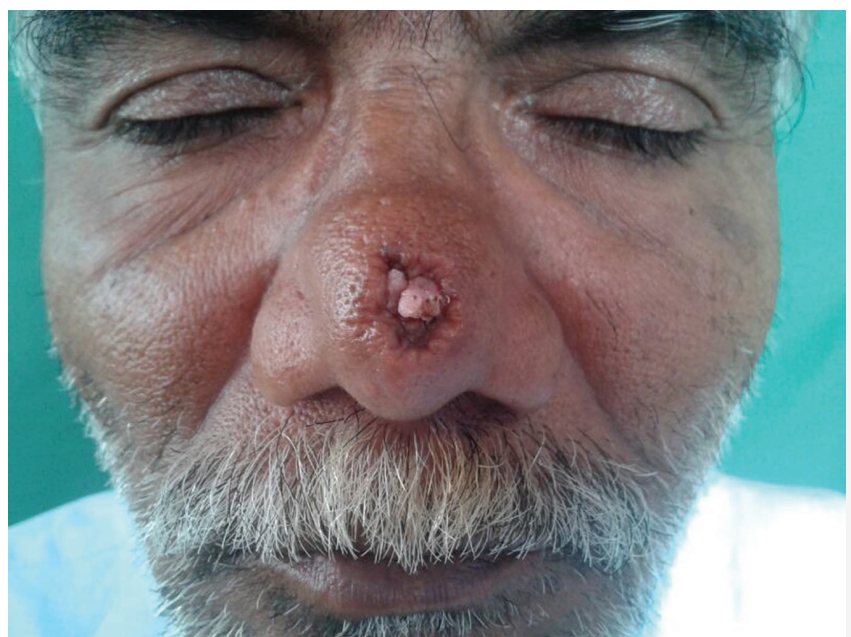

Figure 1. The nodular lesion over nose with surrounding pigmentation and scarring. The edges of the lesion are depressed with nodular pattern in the middle. 


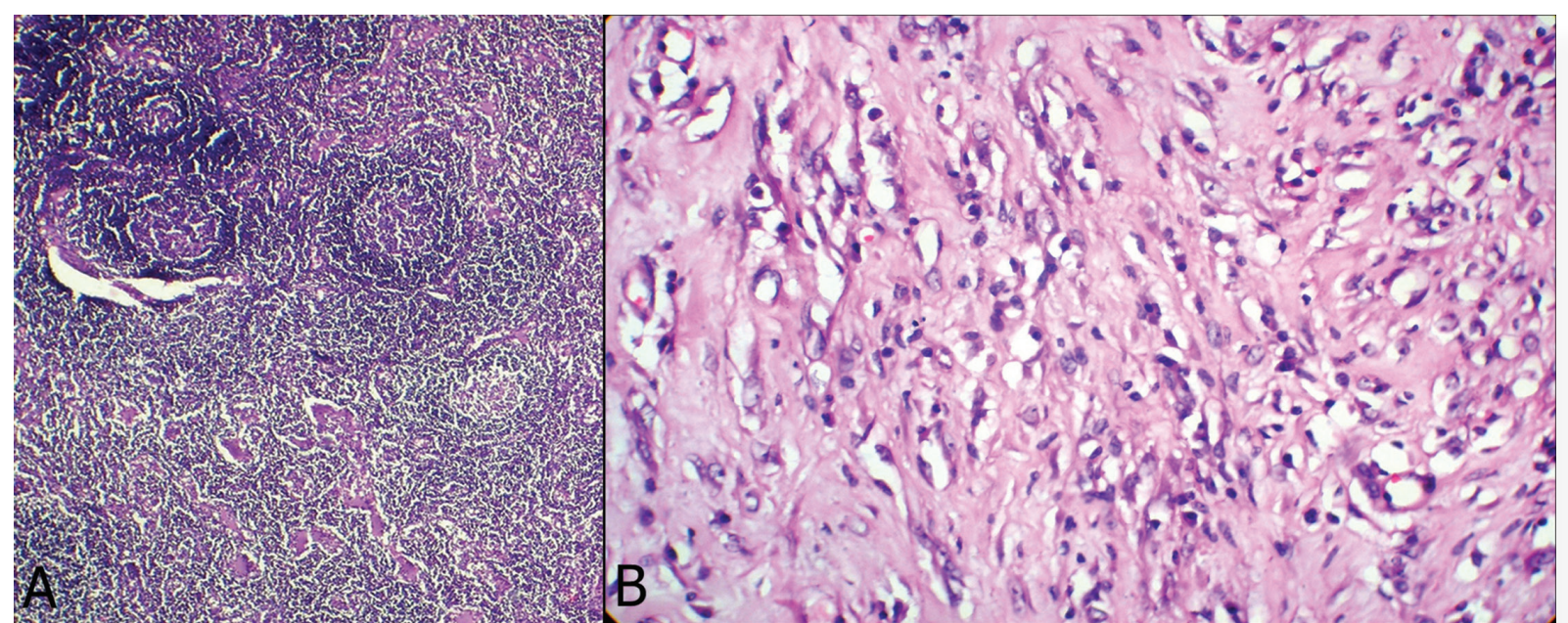

Figure 2A, B. Histopathological: A noticeable whorl patterned arrangement of spindle cells. The nuclei are rod-like and fairly uniform in shape. The stroma is well vascularized with a few areas of hyaline degeneration. Atypia is mild and mitotic figures rare.

\section{Discussion}

First description of leiomyoma was given by Virchow in 1854. He described them as benign smooth muscle neoplasms of the skin [1]. The leiomyoma area thought to originate from the smooth muscle of skin, the arector pili muscles and is hence termed piloleiomyoma. Broadly leiomyoma can be classified as: 1. Piloleiomyomas

2. Angioleiomyomas derived from the smooth muscle in the wall of blood vessels

3. Genital leiomyomas that arise from the Dartos muscle of the genitalia [2].

The inheritance patterns of leiomyoma have been the subject of recent genetic research. Unpredictable autosomal dominant patterns have been described in a few families [3]. Multiple syndromes have also been described with group presentation of uterine fibroids, skin lesions, renal cancer etc. The skin lesions however are difficult to diagnose given the simple presentation as skin nodules.

Differential diagnosis of such nodules include:

\section{Neurofibromas/Fibromas}

2. Myomas

3. Xanthomas

4. Dermatofibroma

5. Mastocytosis

6. Glomus tumor

7. Neurilemmoma etc.

Individual leiomyomas are smooth, firm papules or nodules, usually smaller than $2 \mathrm{~cm}$ in diameter, and reddish brown. Many are tender to palpation. Leiomyoma occurs predominantly on the lower extremities, less commonly on the head or trunk, and rarely on the hands or in the mouth [4-6]. Leiomyomas generally are asymptomatic. In our case, the patient had occasional itching and pain which was rare considering the nature of lesion. Such symptoms can hardly be attributed to piloleiomyomas. Pain in the nodules can however be seen in angioleiomyomas.

Asymptomatic lesions can be left untreated. Medical management has a limited role in the management of these lesions. Pharmacologic intervention has been used to alleviate pain. Options include calcium channel blockers, e.g., nifedipine, alpha blockers, e.g, phenoxybenzamine, Gabapentin, BOTOX, etc [4]. Surgical excision can be done for painful lesions or for cosmetic concern. Recurrence is rare in solitary lesions.

\section{REFERENCES}

Virchow R. Ueber Makroglossie und pathologische Neubildung quergestreifter Muskelfasern. Virchows Arch (Pathol Anat). 1854;7:126-38

2. Fisher WC, Helwig EB. Leiomyomas of the skin. Arch Dermatol. 1963;88:510- 20 .

3. Tomlinson IP, Alam NA, Rowan AJ, Barclay E, Jaeger EE, Kelsell $\mathrm{D}$, et al. Germline mutations in FH predispose to dominantly inherited uterine fibroids, skin leiomyomas, and papillary renal cell cancer. Nat Genet. 2002;30:406-10.

4. Brooks JK, Nikitakis NG, Goodman NJ, Levy BA. Clinicopathologic characterization of oral angioleiomyomas. Oral Surg Oral Med Oral Pathol Oral Radiol Endod. 2002;94:221-7.

5. Nagata S, Nishimura H, Uchida M, Hayabuchi N, Zenmyou M, Fukahori S. Giant angioleiomyoma in extremity: report of two cases. Magn Reson Med Sci. 2006;5:113-8.

6. Yagi K, Hamada Y, Yasui N. A leiomyoma arising from the deep palmar arterial arch. J Hand Surg [Br]. 2006;31:680-2.

7. Onder M, Adisen E. A new indication of botulinum toxin: leiomyoma-related pain. J Am Acad Dermatol. 2009;60:325-8.

Copyright by Harinatha Sreekar, et al. This is an open access article distributed under the terms of the Creative Commons Attribution License, which permits unrestricted use, distribution, and reproduction in any medium, provided the original author and source are credited. 